\title{
Isolation and identification of Salmonella from diarrheagenic infants and young animals, sewage waste and fresh vegetables
}

\author{
Amruta Nair ${ }^{1}$, T. Balasaravanan ${ }^{2}$, S. V. S Malik ${ }^{1}$, Vysakh Mohan ${ }^{1}$, Manesh Kumar ${ }^{1}$, Jess Vergis ${ }^{1}$ and Deepak B. Rawool
}

1. Division of Veterinary Public Health, Indian Veterinary Research Institute, Bareilly, Uttar Pradesh, India; 2. Department of Biotechnology, Nehru Arts \& Science College, Bharathiar University, Coimbatore, Tamil Nadu, India.

Corresponding author: Amruta Nair, e-mail: amrutanairk@gmail.com, TB: balsarvan@rediffmail.com,

SVSM: svsmalik@gmail.com, VM: vysakhmohanvet@gmail.com, MK: vetmanesh@gmail.com, JV: itzjessvergis@gmail. com, DBR: deepak.rawool@yahoo.com

Received: 13-02-2015, Revised: 23-04-2015, Accepted: 29-04-2015, Published online: 27-05-2015

doi: 10.14202/vetworld.2015.669-673 How to cite this article: Nair A, Balasaravanan T, Malik SVS, Mohan V, Kumar M, Vergis J, Rawool DB (2015) Isolation and identification of Salmonella from diarrhoeagenic infants and young animals, sewage waste and fresh vegetables, Veterinary World 8(5):669-673.

\begin{abstract}
Aim: This study was carried out to determine the prevalence, distribution, and identification of Salmonella serotypes in diarrheagenic infants and young animals, including sewage waste and fresh vegetables.

Materials and Methods: A total of 550 samples were processed for the isolation of Salmonella spp., using standard microbiological and biochemical tests. Further polymerase chain reaction (PCR) detection of Salmonella genus was carried out using self-designed primers targeting invA gene and thereafter identification of important serotypes namely Salmonella Enterica serovar Typhimurium, Salmonella Enterica serovar Enteritidis, Salmonella Enterica serovar Typhi was performed using published standardized multiplex PCR.
\end{abstract}

Results: An overall low prevalence of $2.5 \%$ (14/550) was observed. The observed prevalence of Salmonella spp. in diarrheagenic infants was 1.2\% (05/400), diarrheagenic young animals $4 \%(02 / 50)$, sewage waste $10 \%(05 / 50)$, and fresh vegetables $4 \%(02 / 50)$, respectively. In diarrheagenic infants, of the five Salmonella isolates identified, two were Salmonella Typhimurium, two Salmonella Enteritidis, and one was unidentified and hence designated as other Salmonella serovar. All the Salmonella isolates identified from diarrheagenic young animals and sewage waste belonged to other Salmonella serovar, whereas, of the two isolates recovered from fresh vegetables, one was identified as other Salmonella serovar, and one as Salmonella Typhimurium, respectively.

Conclusion: Isolation of Salmonella spp. especially from sewage waste and fresh vegetable is a matter of great concern from public health point of view because these sources can accidentally serve as a potential vehicle for transmission of Salmonella spp. to animals and human beings.

Keywords: inv A, isolation, multiplex polymerase chain reaction, Salmonella.

\section{Introduction}

Foodborne diseases with its clinical complexities are a potential public health threat worldwide and have a large economic impact across the globe. Foodborne diseases are caused by approximately 250 pathogens including bacteria, viruses, and parasitic organisms [1]. Salmonella species are most frequently reported cause of foodborne illness in both humans and animals. The gastroenteritis caused by non-typhoidal Salmonella contributes to global public health burden with about 93.8 million cases annually [2]. Salmonella infections are largely classified into four clinical types [3]. First, gastroenteritis caused by Salmonella Enterica serovar Typhimurium; second, Bacteremia, osteomyelitis, reactive arthritis due to Salmonella Typhimurium and Salmonella Enteritidis infection; third, enteric fever caused by Salmonella Typhi and Salmonella Paratyphi and lastly, a carrier state in persons with previous infections [4,5].

Copyright: The authors. This article is an open access article licensed under the terms of the Creative Commons Attributin License (http:// creative commons.org/licenses/by/2.0) which permits unrestricted use, distribution and reproduction in any medium, provided the work is properly cited.
Non-typhoidal Salmonella is ranked second in its contribution to domestically acquired foodborne illnesses and accounts for $35 \%$ of hospitalization and $28 \%$ mortality [6]. Of the various Salmonella serotypes, Salmonella Enteritidis and Salmonella Typhimurium are the most common serotypes reported from human clinical cases. In developing countries like India, foodborne illness are mostly under reported; however in the past 29 years (1980-2009) 3485 persons have been affected from 37 Salmonella related outbreaks [7].

Salmonella infections have been recognized in all the countries, but appear to be more prevalent in areas of intensive animal husbandry, especially poultry, cattle, and pig farming [8]. In general, Salmonella contamination is implicated in a wide range of products of animal and plant origin. The primary hosts for non-typhoidal Salmonella include cattle, swine, poultry, wild birds (gulls), and pets which excrete this organism in feces, which in turn, can contaminate various food sources and environment [9]. Many asymptomatic livestock play a role as carriers of human pathogens and their feces may contain high concentrations of the organisms which are rarely detected during routine ante-mortem examination [10]. 
In India, to the best of our knowledge, studies addressing isolation, identification and distribution of Salmonella serotypes from varied sources are very few and hence the present study was undertaken with an aim to determine the prevalence and distribution pattern of important Salmonella serotypes in diarrheagenic human infants and young animals, sewage waste and fresh vegetables.

\section{Materials and Methods}

\section{Ethical approval}

All the procedures have been carried out in accordance with the guidelines laid down by the Institutional Ethics Committee and in accordance with local laws and regulations. In case of human infants, the diarrheal stool samples were randomly collected, primarily from Medical colleges, pediatric hospitals, and home settings, where the cases of diarrhea were observed. World Health Organization (2009) criteria for acute diarrheal episodes were fulfilled by all the children evaluated at hospitals, health care facilities, and home. Samples were collected only after obtaining informed consent either from the parents of infants or with the help of medical practitioners. The diarrheic fecal samples from young animals were collected from Veterinary dispensaries, organized or unorganized farms after having proper consent from animal owners.

\section{Collection of samples}

A total of 550 samples, from Telangana, Chennai, Maharashtra, Goa, Uttar Pradesh, and Rajasthan comprising of 400 stool samples from diarrheagenic infants ( $<5$ years), 50 fecal samples from diarrheic young animals, 50 samples of fresh vegetables viz., mint leaves, tomato, cilantro leaves and 50 samples from sewage, were collected and screened in the present study. All the samples except fresh raw vegetables were collected aseptically using Cary Blair transport swabs (Hi Media Labs, Mumbai, India) and were transported to the laboratory within a week for further isolation and identification studies.

\section{Isolation of Salmonella}

Isolation of Salmonella was performed as recommended by FDA [11]. In brief, $1 \mathrm{ml}$ of the sample from the transport swab was inoculated in $9 \mathrm{ml}$ of buffered peptone water (Hi Media) and incubated at $37^{\circ} \mathrm{C}$ for $18 \mathrm{~h}$ for pre-enrichment. Further, for selective enrichment $0.1 \mathrm{ml}$ of the pre-enriched inoculum was transferred to $10 \mathrm{ml}$ of Rappaport-Vassiliadis broth (Hi Media) and incubated at $42^{\circ} \mathrm{C}$ for $24 \mathrm{~h}$. After enrichment, a loopful $(10 \mu \mathrm{l})$ of inoculums was then streaked on xylose lysine desoxycholate (XLD) agar (Hi Media) and incubated at $37^{\circ} \mathrm{C}$ for 24 h. The presumptive Salmonella colonies (4-5 colonies/plate) appearing slightly transparent red halo with a black center surrounded by a pink-red zone on XLD agar were screened further for its biochemical characterization.

\section{Identification of Salmonella}

Biochemical characterization

The presumptive colonies of Salmonella were further subjected to biochemical tests viz., triple sugar iron (TSI), ortho-nitrophenyl galactosidase (ONPG), urease broth, indole, methyl red, Voges-Proskauer and Citrate test (IMViC) as per the standard test protocol described in Bacteriological Analytical Manual FDA [11].

\section{Genus identification of Salmonella isolates by poly- merase chain reaction (PCR)}

The biochemically positive Salmonella isolates were reconfirmed for genus Salmonella by employing PCR targeting genus-specific inv A gene, with an amplicon size of $423 \mathrm{bp}$, using a self-designed primers (Table-1). In brief, the DNA was extracted from Salmonella isolates using QIAamp DNA extraction kit as per the instructions recommended by the manufacturer. The targeted gene amplification by PCR was carried out with following PCR reaction mixture, which comprised of $2.5 \mu \mathrm{l}$ of $10 \times$ PCR buffer $(100 \mathrm{mM}$ Tris- $\mathrm{HCl}$ buffer, $\mathrm{pH} 8.3$ containing $500 \mathrm{mM} \mathrm{KCl}, 15 \mathrm{mM} \mathrm{MgCl}$, and $0.01 \%$ gelatin), $1 \mu \mathrm{l}$ of $2.5 \mathrm{mM}$ dNTP mix (a final concentration of $1 \mathrm{mM}$ ), $1 \mu \mathrm{l}$ of $50 \mathrm{mM} \mathrm{MgCl} 2$, and $10 \mathrm{pmol}$ of forward and reverse primer (Eurofins Pvt. Ltd., Bangaluru), $1 \mathrm{U}$ of Taq DNA polymerase (3B Black Bio, Spain), $4 \mu 1$ of DNA as a template, and nuclease free water to make up the reaction volume of $25 \mu \mathrm{L}$. The PCR amplification was performed in Mastercycler Pro Thermocycler (Eppendorf, Germany). The cycling conditions after gradient PCR were optimized with an initial denaturation at $94^{\circ} \mathrm{C}$ for $5 \mathrm{~min}$, followed by 35 cycles of denaturation at $94^{\circ} \mathrm{C}$ for $30 \mathrm{~s}$, annealing at $56^{\circ} \mathrm{C}$ for $1 \mathrm{~min}$, and extension at $72^{\circ} \mathrm{C}$ for $1 \mathrm{~min} 30 \mathrm{~s}$, followed by $10 \mathrm{~min}$ of final extension at $72^{\circ} \mathrm{C}$ and hold at $4^{\circ} \mathrm{C}$. The amplified PCR products were resolved by agarose gel electrophoresis, using $1.5 \%$ agarose gel stained with ethidium bromide $(0.5 \mu \mathrm{g} / \mathrm{ml})$ and visualized and documented using UV gel documentation system (UVP Gel Seq Software, England). The presence of amplicon at $423 \mathrm{bp}$ was confirmed as Salmonella genus (Figure-1).

\section{Serotype identification of Salmonella isolates by multiplex PCR}

The serotype identification namely Salmonella Enteritidis, Salmonella Typhi, and Salmonella Typhimurium for the confirmed Salmonella isolates was carried out using multiplex PCR assay as described earlier [12] with slight modifications. The details of primers, genes targeted and the amplicon size for the serotypes mentioned above are presented in Table-1. In brief, the optimized PCR reaction mixture consisted of $2.5 \mu 1$ of $10 \times$ PCR buffer, $3 \mu 1$ of $50 \mathrm{mM}$ of $\mathrm{MgCl} 2,3 \mu \mathrm{l}$ of $2.5 \mathrm{mM}$ of dNTP mix, $1 \mathrm{U}$ of Taq polymerase, $10 \mathrm{pmol}$ of each set of forward primer, and $10 \mathrm{pmol}$ of each set of reverse primer (Eurofins Pvt. Ltd., Bangaluru), $5 \mu 1$ of DNA as a template and nuclease free water to make $25 \mu \mathrm{l}$ of reaction volume. 
The PCR cycling conditions were programmed with an initial denaturation step of $5 \mathrm{~min}$ at $94^{\circ} \mathrm{C}$; followed by 35 cycles, each with denaturation at $94^{\circ} \mathrm{C}$ for $30 \mathrm{~s}$, annealing at $57^{\circ} \mathrm{C}$ for $1 \mathrm{~min}$., extension at $72^{\circ} \mathrm{C}$ for $1 \mathrm{~min} 30 \mathrm{~s}$ and finally the final extension was performed at $72^{\circ} \mathrm{C}$ for $7 \mathrm{~min}$ and hold at $4^{\circ} \mathrm{C}$. The amplified PCR products were resolved by agarose gel electrophoresis, using $1.5 \%$ agarose gel stained with ethidium bromide $(0.5 \mu \mathrm{g} / \mathrm{ml})$ and visualized and documented using UV gel documentation system (UVP Gel Seq Software, England).

\section{Result}

The results of isolation of Salmonella spp. and its further serotype identification employing multiplex PCR are presented in Table-2. In brief, on microbiological analysis of 550 samples, 92 samples revealed presumptive Salmonella colonies on XLD agar plate. Further, on biochemical characterization, only 14 samples revealed biochemical profile suggestive of Salmonella genus. All the 14 isolates were TSI positive, urease negative, ONPG negative, indole negative, methyl red positive, Voges Proskauer negative, and Citrate test positive, respectively. All these biochemically confirmed Salmonella isolates were reconfirmed using genus-specific invA gene PCR (Table-2).

Overall, in the present study a low prevalence of $2.5 \%(14 / 550)$ was observed for Salmonella spp. The

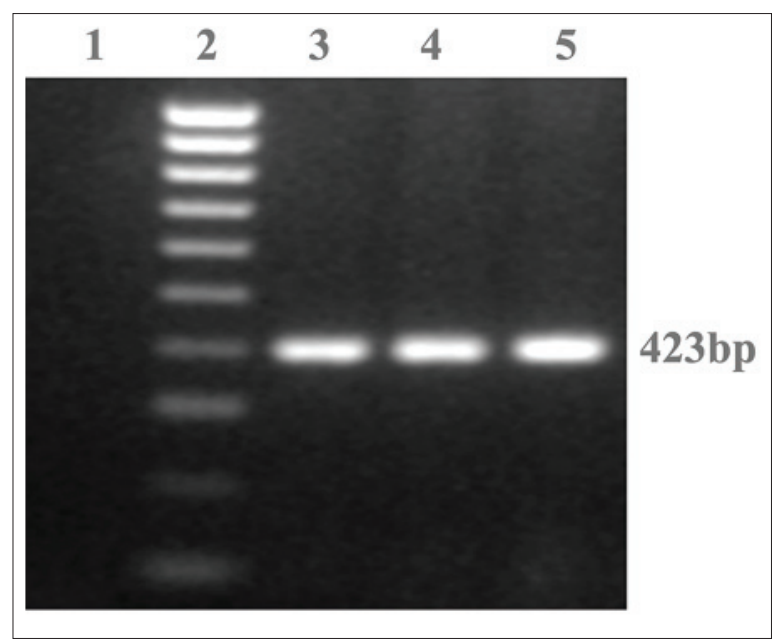

Figure-1: Representative agarose gel analysis of PCR assay targeting invA gene in Salmonella isolates. Lane 1: Negative control, Lane 2: 100 bp DNA ladder, Lane 3: S. Typhimurium, Lane 4-5: Positive samples observed source wise isolation rate of Salmonella spp. in diarrheagenic infants was $1.2 \%(05 / 400)$, diarrheagenic young animals $4 \%(02 / 50)$, sewage waste $10 \%$ $(05 / 50)$, and fresh vegetables $4 \%(02 / 50)$, respectively. The details of serotype identified from the respective source are presented in Table-2 and Figure-2.

\section{Discussion}

In developing countries, Salmonella is considered to be the prime etiological agent in causing foodborne diseases and childhood morbidity and mortality $[2,13]$. In the present study, all the screened samples, including infant stools were found negative for Salmonella Typhi. This absence of Salmonella Typhi in the present study could be due to effective breastfeeding $[14,15]$. Moreover, it has been reported that the lower incidence of Salmonellosis in Asian countries has been observed in human infants due to their association with higher rates of breastfeeding among their mothers $[16,17]$.

In India, Salmonellosis is endemic in humans, animals, and also associated with foods of animal origin [18-20]. In our study, the overall prevalence of Salmonella in diarrheagenic human infants was $1.2 \%$ and $4 \%$ in diarrheic young animals, which obviously was on the lower side as compared to earlier studies [18-20]. Beside this, in the present study, the serotypes namely Salmonella Enteritidis and Salmonella Typhimurium were identified from human infants and fresh vegetables. Similar serotype isolation/identification of Salmonella Enteritidis and Salmonella Typhimurium has also been reported by several authors from human infants and vegetables [21,22]. Almost all the isolates recovered from animals and sewage wastes were considered as other Salmonella serotypes because only three important serotypes namely Salmonella Enteritidis, Salmonella Typhimurium and Salmonella Typhi were detected by multiplex PCR employed in the present study. These results are in partial agreement with other authors wherein besides Salmonella Enteritidis and Salmonella Typhimurium, other Salmonella serotypes have also been identified in animals and sewage waste [22,23]. Further, in our study bovine and equine samples failed to yield Salmonella isolates, although earlier studies [24,25] have revealed a higher incidence of Salmonella spp. in the said species. There can be several factors behind their absence, but the most important would be the

Table-1: Primer details for identification of genus and serotypes of Salmonella isolates.

\begin{tabular}{|c|c|c|c|c|c|}
\hline Bacteria & Gene targeted & Primers & Primer sequence & Product size (bp) & Reference \\
\hline Salmonella & $\operatorname{Inv} \mathrm{A}$ & $\begin{array}{l}\text { Forward } \\
\text { Reverse }\end{array}$ & $\begin{array}{l}\text { TCG TGA CTC GCG TAA ATG GCG ATA } \\
\text { GCA GGC GCA CGC CAT AAT CAA TAA }\end{array}$ & 423 & This study \\
\hline $\begin{array}{l}\text { Salmonella } \\
\text { Enteritidis }\end{array}$ & $S d f \mathrm{I}$ & $\begin{array}{l}\text { Forward } \\
\text { Reverse }\end{array}$ & $\begin{array}{l}\text { TGT GTT TTA TCT GAT GCA AGA GG } \\
\text { TGA ACT ACG TTC GTT CTT CTG G }\end{array}$ & 304 & $\begin{array}{l}\text { De Freitas } \\
\text { et al. } 2010\end{array}$ \\
\hline $\begin{array}{l}\text { Salmonella } \\
\text { Typhi }\end{array}$ & Via B & $\begin{array}{l}\text { Forward } \\
\text { Reverse }\end{array}$ & $\begin{array}{l}\text { CAC GCA CCA TCA TIT CAC CG } \\
\text { AAC AGG CTG TAG CGA TIT AGG }\end{array}$ & 738 & $\begin{array}{l}\text { De Freitas } \\
\text { et al. } 2010\end{array}$ \\
\hline $\begin{array}{l}\text { Salmonella } \\
\text { Typhimurium }\end{array}$ & Spy & $\begin{array}{l}\text { Forward } \\
\text { Reverse }\end{array}$ & $\begin{array}{l}\text { TTG TTC ACT TIT TAC CCC TGA A } \\
\text { CCC TGA CAG CCG TTA GAT ATT }\end{array}$ & 401 & $\begin{array}{l}\text { De Freitas } \\
\text { et al. } 2010\end{array}$ \\
\hline
\end{tabular}


Table-2: Isolation and identification of Salmonella isolates from various sources.

\begin{tabular}{|c|c|c|c|c|c|c|}
\hline $\begin{array}{l}\text { Sampling } \\
\text { subjects }\end{array}$ & $\begin{array}{l}\text { Source of } \\
\text { sample }\end{array}$ & $\begin{array}{l}\text { Number } \\
\text { of sample } \\
\text { screened }\end{array}$ & $\begin{array}{c}\text { Positive } \\
\text { samples on } \\
\text { microbiological } \\
\text { analysis }\end{array}$ & $\begin{array}{c}\text { Positive } \\
\text { samples on } \\
\text { biochemical } \\
\text { analysis }\end{array}$ & $\begin{array}{l}\text { Genus } \\
\text { specific } \\
\text { PCR } \\
\text { positive }\end{array}$ & $\begin{array}{l}\text { Serotype identified by } \\
\text { multiplex PCR }\end{array}$ \\
\hline \multirow[t]{2}{*}{$\begin{array}{l}\text { Human infants } \\
\text { ( }<5 \text { years })\end{array}$} & Male & 200 & 23 & 2 & 2 & $\begin{array}{l}\text { Salmonella Enteritidis }(n=1) \\
\text { other Salmonella serotypes }(n=1)\end{array}$ \\
\hline & Female & 200 & 30 & 3 & 3 & $\begin{array}{l}\text { Salmonella Enteritidis }(n=1) \text {, } \\
\text { Salmonella Typhimurium }(n=2)\end{array}$ \\
\hline \multirow{3}{*}{$\begin{array}{l}\text { Young animals } \\
\text { ( }<6 \text { months })\end{array}$} & Canine & 25 & 8 & 2 & 2 & Other Salmonella serotypes $(n=2)$ \\
\hline & Bovine & 15 & 3 & 0 & 0 & ND \\
\hline & Equine & 10 & 0 & 0 & 0 & ND \\
\hline \multirow[t]{3}{*}{$\begin{array}{l}\text { Fresh } \\
\text { vegetables }\end{array}$} & $\begin{array}{l}\text { Cilantro } \\
\text { leaves }\end{array}$ & 10 & 5 & 1 & 1 & Salmonella Typhimurium $(n=1)$ \\
\hline & Tomato & 20 & 3 & 1 & 1 & Other Salmonella serotypes $(n=1)$ \\
\hline & Mint leaves & 20 & 0 & 0 & 0 & ND \\
\hline Sewage waste & & 50 & 20 & 5 & 5 & Other Salmonella serotypes $(n=5)$ \\
\hline
\end{tabular}

$\mathrm{ND}=$ Not detected, $\mathrm{PCR}=$ Polymerase chain reaction

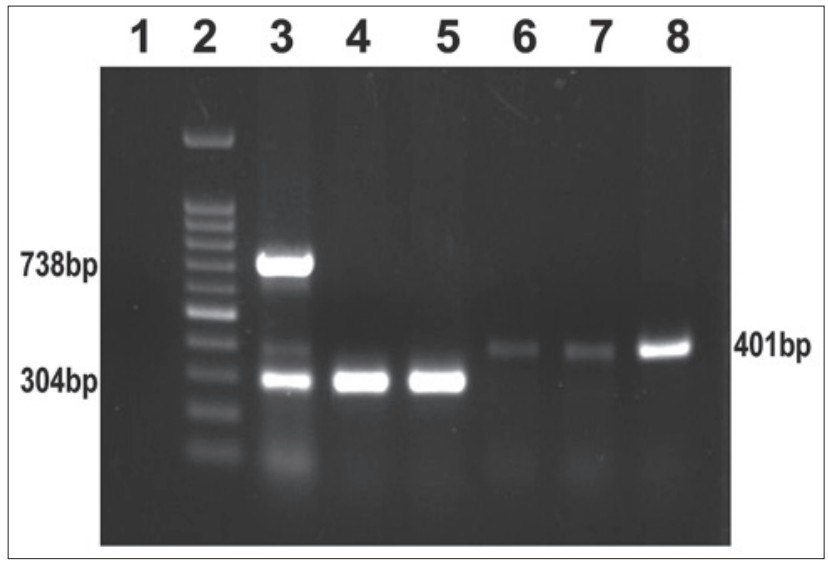

Figure-2: Representative gel analysis of multiplex PCR for identification of Salmonella serotypes.Lane 1: Negative control, Lane 2: 100 bp DNA ladder, Lane 3: Standards (S. Typhi 738 bp, S.Typhimurium 401 bp and S. Enteritidis $304 \mathrm{bp}$ ), Lane 4 - 5: S. Enteritidis isolates, Lane 6 - 8: S. Typhimurium isolates

limited number of samples screened in the present study and further it has been also reported that diseased animals shed Salmonella intermittently, and therefore a minimal 5 consecutive negative fecal cultures is recommended before declaring the animal negative for Salmonellosis [26-28].

In our study, Salmonella isolates were also recovered from fresh vegetables (Tomato, Cilantro leaves), which in most of the countries including India are often consumed raw. Thus, the presence of this pathogen in such vegetables is a matter of concern from food safety point of view. Similar reports on detection of Salmonella from fresh vegetable have also been reported by several authors [29-32]. In general, these pathogenic bacteria are brought into aquatic environments mainly through treated or untreated wastewater release, surface runoffs, and soil leaching which in turn poses a substantial risk of widespread occurrence of diseases [33]. Besides this, Salmonella also have the ability to attach to plant tissue and can survive under adverse temperature conditions due to their effective biofilm formation capability [31,34].

\section{Conclusion}

Isolation of Salmonella spp. especially from sewage waste and fresh vegetables is a matter of great concern from public health point of view because these sources can accidentally serve as a vehicle for transmission of Salmonella spp. to animals and human beings. However, in the light of results from the present study, epidemiological studies addressing the source of transmission in human and animals needs to devised and executed. Furthermore, more focused intervention studies are required to control this pathogen in sewage waste and fresh vegetables.

\section{Authors' Contributions}

DBR and TB have designed and supervised the study. AN has carried out bacterial isolation and molecular characterization. TB, VM, MK, and JV have collected the samples and also helped in characterizing the isolates. AN and VM drafted and reviewed the manuscript. DBR and SVSM have edited the manuscript. All authors read and approved the final manuscript.

\section{Acknowledgments}

The authors are thankful to the Director, Indian Veterinary Research Institute, Izatnagar for providing the necessary facilities to carry out this work. The research work supported by grants from the Department of Biotechnology, Government of India (BT/PR15148/GBD/27/339/2011) to DBR is also duly acknowledged.

\section{Competing Interests} interests.

The authors declare that they have no competing

\section{References}

1. Linscott, A.J. (2011) Food-borne illnesses. Clin. Microbiol. Newsl., 33(6): 41-5. 
2. Majowicz, S.E., Musto, J., Scallan, E., Angulo, F.J., Kirk, M., O'Brien, S.J. and Hoekstra, R.M. (2010) The global burden of non-typhoidal Salmonella gastroenteritis. Clin. Infect. Dis., 50(6): 882-889.

3. Bisi-Johnson, M.A. and Obi, C.L. (2012) Escherichia coli and Salmonella species: Molecular landscape and therapeutic considerations: A review. Adv. Med. Sci., 1(1): 1-16.

4. Owens, M.D. and Warren, D.A. (2009) Salmonella Infection. Emedicine: Emergency MedicineAvailable from: http://www.emedicine.medscapecom/article/785774-overview.html. Accessed on 15-04-2015.

5. Klotchko, A. and Wallace, M.R. (2009) Salmonellosis: Treatment and Medication. Available from: http://www. emedicine.medscape.com/article/228174-overview. Accessed on 15-04-2015.

6. CDC. (2011) Estimates of Foodborne Illness in the United States. Available from: http://www.cdc.gov/foodborneburden/2011-foodborne-estimates.html. Accessed on 15-04-2015.

7. Sudershan, R.V., Kumar, R.N. and Polasa, K. (2012) Foodborne diseases in India - A review. Br. Food J., 114(5): 661-680.

8. OIE. (2008) Salmonellosis - Chapter 2.9.9. In: OIE Terrestrial Manual. Available from: http://www.oie. int/fileadmin/Home/eng/Health_standards/tahm/2008/ pdf/2.09.09_SALMONELLOSIS.pdf. Accessed on $15-04-2015$.

9. CDC. (1999) Section VII-agents summary statements, section VIIA bacterial agents. In: Richmond, J.Y. and McKinney, R.W., editors. Biosafety in Microbiological and Biomedical Laboratories. $4^{\text {th }}$ ed. Government Printing Office, Washington, U.S. p109.

10. EFSA, Panel on Biological Hazards. (2013) Scientific opinion on the public health hazards to be covered by inspection of meat (Bovine animals). EFSA, J., 11(6): 3266, 1-261.

11. Andrews, W.H., Jacobson, A. and Hammack, T.S. (1998) Salmonella. In: Bacteriological Analytical Manual. $8^{\text {th }}$ ed., Ch. 4. Revision A. Available from: http://www. fda.gov/Food/FoodScienceResearch/LaboratoryMethods/ ucm2006949.html. Accessed on16-04-2015.

12. De Freitas, C.G., Santana, Â.P., Da Silva, P.H.C., Gonçalves, V.S.P., Barros, M.D. A.F., Torres, F.A.G. and Perecmanis, S. (2010) PCR multiplex for detection of Salmonella enteritidis, Typhi and Typhimurium and occurrence in poultry meat. Int. J. Food Microbiol., 139(1-2): 15-22.

13. De Freitas Neto, O.C., Penha Filho, R.A.C., Barrow, P. and Berchieri, A Jr. (2010) Sources of human non-typhoid salmonellosis - A review, Rev. Bras. Ciênc. Avic., 12(1): 1-11.

14. Rowe, S.Y., Rocourt, J.R., Shiferaw, B., Kassenborg, H.D., Segler, S.D., Marcus, R. and Slutsker, L. (2004) Breastfeeding decreases the risk of sporadic salmonellosis among infants in food net sites. Clin. Infect. Dis., 38(3): S262-S270.

15. Ryan, A.S., Zhou, W. and Gaston, M.H. (2004) Regional and socio-demographic variation of breastfeeding in the United States, 2002. Clin. Pediatr., 43(9): 815-824.

16. CDC. (2010) Breastfeeding Among U.S. Children Born 2001-2011. In: National Immunization Survey NIS Data. Provisional breastfeeding rates by socio-demographic factors, among children born in 2007. Available from: http://www. cdc.gov/breastfeeding/data/nis_data. Accessed 16-04-2015.

17. Cheng, L.H., Crim, S.M., Cole, C.R., Shane, A.L., Henao, O.L. and Mahon, B.E. (2013) Epidemiology of infant salmonellosis in the United States, 1996-2008: A foodborne diseases active surveillance network study. $J$. Pediatr. Infect. Dis. Soc., 4(1): 1-8.

18. Verma, J.C., Singh, V.P., Singh, B.R. and Gupta, B.R. (2001) Occurrence of Salmonella serotypes in animals in India VII. Indian, J. Comp. Microbiol. Immunol. Infect. Dis., 22(1): 51-55.
19. Thapliyal, D.C. (1999) Diseases caused by viruses. In: Diseases of animals transmissible to man. $1^{\text {st }}$ ed. International Book Distributing Company, Lucknow. p57-71.

20. WHO. (2010) Laboratory Protocol Isolation of Salmonella spp. From Food and Animal Faeces. In: Global Foodborne Infections Network. WHO, Atlanta, GA; USA. $5^{\text {th }}$ ed. p4-8.

21. Rahman, H., Streckel, W., Prager, R. and Tschäpe, H. (2004) Presence of sopE gene and its phenotypic expression among different serovars of Salmonella isolated from man and animals. Indian, J. Med. Res., 120(1): 35-38.

22. Cellucci, T., Seabrook, J.A., Chagla, Y., Bannister, S.L. and Salvadori, M.I. (2010) A 10-year retrospective review of Salmonella infections at the children's hospital in London, Ontario. Can. J. Infect. Dis. Med. Microbiol., 21(2): 78.

23. Smith-Palmer A., Stewart, W.C., Mather, H., Greig, A., Cowden, J.M. and Reilly, W.J. (2003) Epidemiology of Salmonella enterica serovars enteritidis and typhimurium in animals and people in Scotland between 1990 and 2001. J. Vet. Rec., 153(17): 517-520.

24. Bagudo, A.I., Tambuwal, F.M., Faleke, O.O., Egwu, O.O. and Aliero, A.A. (2014) Prevalence of Salmonella serotypes in Sokoto abattoir effluents and vegetables cultivated around the abattoir. Microbiol. Res. Int., 2: 13-17.

25. Henriksen, S.W.M., Orsel, K., Wagenaar, J.A., Miko, A. and Duijkeren, E. (2004) Animal-to-human transmission of Salmonella typhimurium DT104A variant. Emerg. Infect. Dis., 10(12): 2225-2257.

26. Alao, F., Kester, C., Gbagba, B. and Fakilede, F. (2012) Comparison of prevalence and antimicrobial sensitivity of Salmonella typhimurium in apparently healthy cattle and goat in Sango-Ota, Nigeria. Internet J. Microbiol., 10(2).

27. Zahran, R. and El-Behiry, A. (2014) Prevalence, molecular identification and virulence attributes of Salmonella serovars isolated from feces of diarrheic cow and buffalo-calves. Int. J. Curr. Microbiol. App. Sci., 3(11): 9-27.

28. Smith, B.P., Reina-Guerra, M. and Hardy, A.J. (1978) Prevalence and epizootiology of equine salmonellosis. $J$. Am. Vet. Med. Assoc., 172(3): 353-356.

29. Quiroz-Santiago, C., Rodas-Suárez, O.R., Vázquez, Q., Carlos, R., Fernández, F.J., Quinones-Ramirez, E.I. and Vazquez-Salinas, C. (2009). Prevalence of Salmonella in vegetables from Mexico. J. Food Prot., 72(6): 1279-1282.

30. Singh, B.R., Singh, P., Agrawal, S., Teotia, U., Verma, A., Sharma, S. and Kant Agarwal, R. (2007). Prevalence of multidrug resistant Salmonella in Coriander, mint, carrot, and radish in Bareilly and Kanpur, Northern India. Foodborne, Pathog. Dis., 4(2): 233-240.

31. Sant'Ana, A.S., Barbosa, M.S., Destro, M.T., Landgraf, M. and Franco, B.D. (2012) Growth potential of Salmonella spp. and Listeria monocytogenes in nine types of readyto-eat vegetables stored at variable temperature conditions during shelf-life. Int. J. Food Microbiol., 157(1): 52-58.

32. Nillian, E., Ching, C.L., Fung, P.C., Robin, T., Anyi, U., Chilek, T.Z.T. and Nishibuchi, M. (2011) Simultaneous detection of Salmonella spp., Salmonella enteritidis and Salmonella typhimurium in raw salad vegetables and vegetarian burger patties. Food Nutr. Sci., 2(10): 1077-1081.

33. James, A.E., Ian, P., Helen, S. and Sojka, R.E. (2003) Polyacrylamide $+\mathrm{A} 12(\mathrm{SO} 4) 3$ and polyacrylamide $+\mathrm{CaO}$ remove coliform bacteria and nutrients from swine wastewater. Environ. Res., 121(3): 453-462.

34. Sheffield, C.L. and Crippen, T.L. (2012) Invasion and survival of Salmonella in the environment: The role of biofilms. In: Kumar, Y., editor. Publisher: In Tech. Available from: http:/www. Intech open. com/articles/show/ title/invasion-and-survival-of-Salmonella-in-the-environment-the-role-of-biofilms. Accessed on16-04-2015 ISBN 978-953-307-781-9, 576. DOI: 10.5772/2471. 